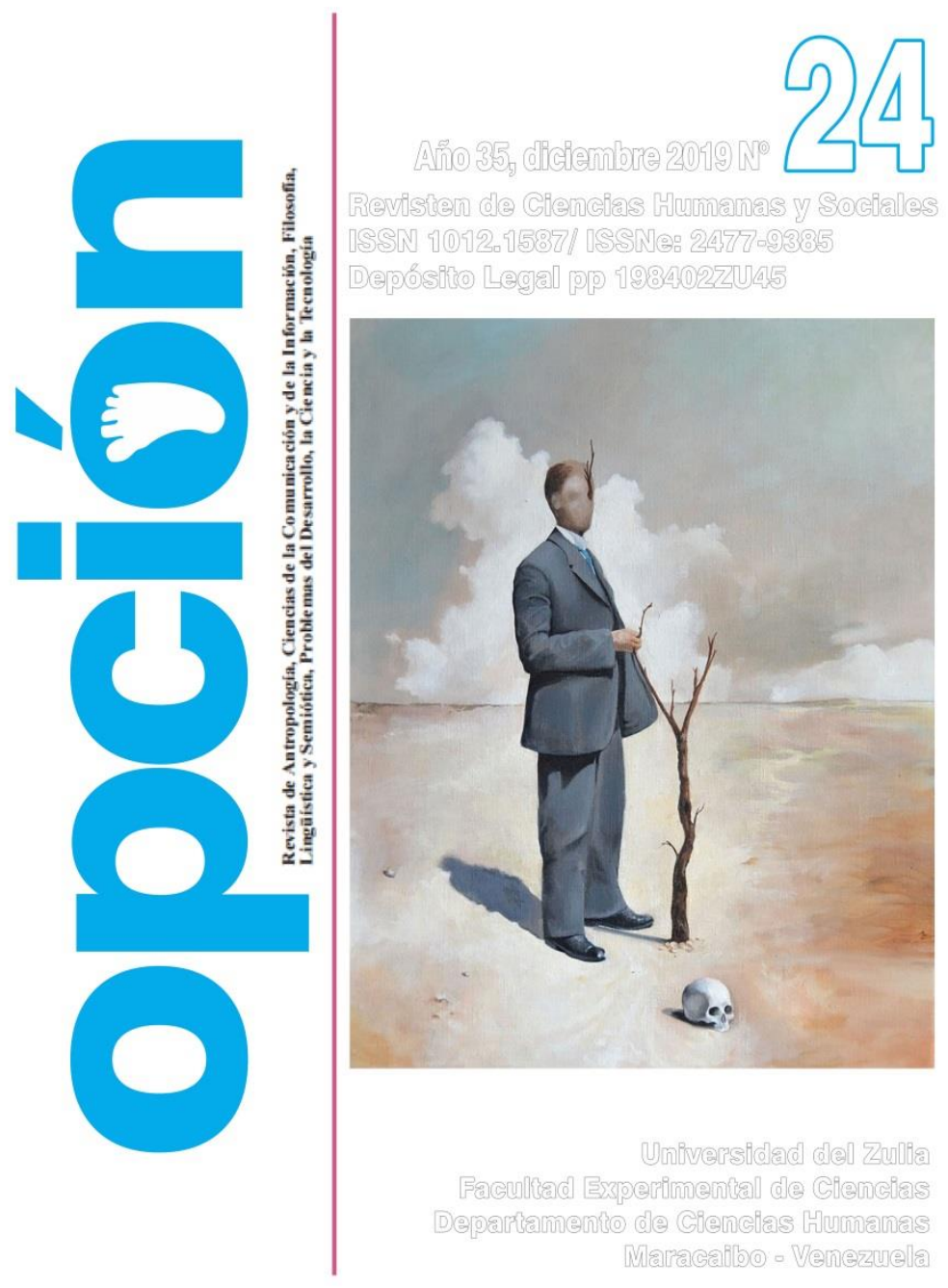





\title{
The sustainability of public debt
}

\author{
Ebrahim Merza ${ }^{1}$ \\ Kuwait University, Kuwait \\ Ebrahim@ac.ku
}

\author{
Eman Maghareez, Mohammad Alawin \& Alaaeddin Al- \\ Tarawneh $^{2}$ \\ The University of Jordan, Jordan \\ Maghareez@ac.jo, Alawin@ac.jo, Al-Tarawneh@ac.jo
}

\begin{abstract}
The primary objective of this study to examine the sustainability of public finance and debt in Jordan. This paper will use the method of Fully Modified Least Squares (FMOLS). The results show that public finance is unable to stabilize the ratio of public debt to GDP at the target. However, for some measures, there was the sustainability of public debt, but it was weak. In conclusion, it is necessary to comprehensively review all items of the public expenditure, prevent unnecessary spending, and direct spending towards productive projects.
\end{abstract}

Keywords: Sustainability, Public, Debt, GDP, Cointegration.

\section{La sostenibilidad de la deuda pública}

\section{Resumen}

El objetivo principal de este estudio es examinar la sostenibilidad de las finanzas públicas y la deuda en Jordania. Este documento utilizará el método de mínimos cuadrados totalmente modificados (FMOLS). Los resultados muestran que las finanzas públicas no pueden estabilizar la proporción de deuda pública / PIB en el objetivo. Sin embargo, para algunas medidas, existía la 
sostenibilidad de la deuda pública, pero era débil. En conclusión, es necesario revisar exhaustivamente todas las partidas del gasto público, evitar gastos innecesarios y gastos directos hacia proyectos productivos.

Palabras clave: Sostenibilidad, Público, Deuda, PIB, Cointegración.

\section{INTRODUCTION}

Many economic theories have attempted to interpret and analyze economic growth. The classical theory showed that capital accumulation, which comes mainly from savings, is the basis of economic growth. Economic growth is one of the fundamental objectives that any country seeks to achieve. Basically, it implies a better life for the citizens of that country. Low economic growth rates might be caused by the failure of government policies to reduce the ratio of public debt to GDP, the inadequacy of natural resources of the country, and the lack of sufficient capital for investment. Capital plays a major role in economic growth, as an important input to the production process. Many developing countries tried to borrow internally or externally to finance fill the capital gap.

History shows that many countries resorted to foreign sources to meet the shortfall in savings. In recent decades, the problem of indebtedness has worsened (OMAR, 2003; SHABBIR, ABBAS, AMAN, \& ALI, 2019).). The public debt of many countries has escalated to critical levels that have negatively impacted the process of economic growth. A large part of the government proceeds has to be 
allocated for debt service. This situation has raised the debate about the future financial challenges that face these countries and how to prevent them from falling into the problem of stumbling in their debt service (CONSIDINE \& GALLAGHER, 2008).

Like any emerging economy with few economic resources, Jordan is continually relying on loans to finance development plans. In the 1980s, the Jordanian dinar lost $50 \%$ of its value because of the economic conditions in Jordan that resulted from the increase in the budget deficit. In addition, the low remittances of foreign workers affected Jordan's ability to meet its debt service obligations. Over time, the burden of the external loans has increased significantly, resulting in reliance on the internal public debt, which has become comparable to the size of external debt. These developments made it important to study both the internal and external debts of Jordan and its impact on the Jordanian economy (EDWARD, 2002; NIKKU, \& RAFIQUE, 2019).

The public debt of a country grows because of the need to cover the deficit in its public budgets. In theory, it is assumed that governments will set specific targets for the deficit so that borrowing will be limited to amounts that the government can service and still fulfill their obligations. Hence, the issue of sustainability of debt becomes an important issue for developing countries (MENDOZA \& OVIEDO, (2009; AKHTAR, ARSHAD, MAHMOOD, \& AHMED, 2018).

Jordan has faced many events that have challenged the ability of the government to sustain the level of public debt. Since 2011, large 
numbers of Syrian refugees have emigrated to Jordan. Jordan's supply of Egyptian gas was interrupted; hence Jordan has been forced to import gas with high costs from other alternatives. In addition, the National Electricity Company of Jordan has large losses that the government has to cover (HERNDON, ASH \& POLLIN, 2013).

Data indicate an increase in the public debt in Jordan from 6.3 billion JD in 2000 to 7.5 billion JD in 2005. From 2006 to 2010, public debt jumped by $56 \%$, at an annualized rate of $11.2 \%$. This clearly highlights the debt problem through the rapid acceleration in debt volume. In 2011, 2013, 2015, and 2018, the ratio of public debt to GDP was $65.4 \%, 80.0 \%, 84.9 \%$, and $89.7 \%$, respectively. Ratios this high could lead to a large debt problem that would impede development projects (BELHOCINE \& DELEBRA, 2013).

Researchers have heavily explored tackling the problems of public debt at both theoretical and practical levels. In addition, policymakers have adopted different programs for economic reforms. Despite these actions, the reality still tells the existence of public debt problems (FEREDE, 2005).

As mentioned, Jordan suffers increasing levels of public debt and that means a continual increase in the burden of debt service. Yet, sustainable public debt can contribute to the economic and social stability of any country. Therefore, the main objective of this study will be to analyze and evaluate the sustainability of the Jordanian public debt and the ability to service it (JUNOHAT, 2006).

The remainder of this paper is organized in the following order. Sections 2 and 3 introduce the theoretical framework and the literature 
review, respectively. Section 4 analyzes debt sustainability indicators in Jordan. Section 5 presents the methodology and results. Finally, Section 6 encompasses the conclusions.

Debt to GDP ratio: The debt to GDP ratio is one of the most frequently used indicators in clarifying the degree of indebtedness. It was one of the indicators adopted in accordance with the Maastricht Treaty of accession to the European Union. The treaty requires that the total of internal and external debt does not exceed $60 \%$ of GDP. The debt to GDP indicator is known as the non-ponzi condition (BAGHDADI, 2011).

The ratio of public debt to GDP reached excessive values at the end of the 1980s and the early 1990s, which was a result of some political and economic conditions in the region. After that, this ratio decreased gradually to reach a reasonable percentage of $54.8 \%$ in 2008. The ratio rose to $92.4 \%$ in 2015 and peaked at $94.4 \%$ in 2018 . Obviously, these recent ratios exceed that set by the Jordanian public debt law. These high ratios of public debt to GDP pose a threat to public finance policies. Therefore, it is necessary to work on stabilizing this ratio at optimal levels to achieve positive rates of economic growth.

BLANCHARD (1990) proposed an indicator of debt sustainability to assess the effectiveness of the taxation policy in maintaining a certain percentage of public debt to GDP. The sustainability is defined as maintaining a certain percentage of public debt to GDP. This measure is based on calculating the ratio of taxes to 
GDP needed to create sustainability of the ratio of public debt to GDP. The basic equation for this indicator is:

$$
\mathrm{T}^{*}=\mathrm{g}_{\mathrm{t}}-\left(\mathrm{n}_{\mathrm{t}}-\mathrm{r}_{\mathrm{t}}\right) \mathrm{b}_{\mathrm{t}}
$$

where: $T^{*}$ is the ratio of taxes to GDP required to stabilize the ratio of public debt to GDP; $\mathrm{g}_{\mathrm{t}}$ is the proportion of government expenditures without interest payments to GDP; $n_{t}$ is the GDP growth rate; $r_{t}$ is the interest rate on public debt; and $b_{t}$ is the ratio of public debt to GDP.

The tax gap is the difference between the ratio of actual taxes to GDP and the ratio required to stabilize the ratio of public debt to GDP. This gap increased significantly during the years 1987, 1988, and 1989, which could be attributed to the excessive increase in the volume of public debt at the end of the 1980s. However, the gap was at low levels during the years 1982, 1983, and 1984.

Although the gap was significantly reduced in 1992 to 7.6, it returned and expanded significantly until the end of 1999. In 2006 and 2008 the actual tax revenue was slightly less than the target by 2.3 and 1.7, respectively; after those years, it increased again. In 2015, the actual target ratio increased by 10.5 . In this year, taxes clearly could not stabilize the ratio of public debt to GDP.

\section{METHODOLOGY}

A number of methods that have been applied in other studies will be used to measure the sustainability of public debt to assess 
Jordan's financial stability. These measures help to assess the country's indebtedness and the likelihood of becoming a heavily indebted country. Therefore, these measures serve as an early warning to potential crises. The most important measures are explained in the following discussion.

Under this method, the sustainability of public debt is measured by comparing the growth rate of real GDP to the real interest rate. If the growth rates of real GDP are higher than or equal to real interest rates, it means the ratio of the public debt of GDP is at a level that the government can handle. If the opposite is true, then the government's ability to sustain public debt becomes weak and not feasible. At that point, the government needs to undertake some effective steps to improve debt management.

Real GDP growth rates were higher than real interest rates for most of the study period. Although the differences are not big, this indicates that public debt is sustainable, according to this measure. However, during the years 1983, 1985, and 1989, real interest rates were higher than real growth rates, underlining the weakness of this sustainability.

According to this method, the income elasticities of revenues and expenditures are calculated by estimating the following two equations (ABDUL-RAHIM, SHIBANI, SHAKORY, 2013):

$$
\begin{aligned}
& \log \mathrm{REV}=\mathrm{a}_{0}+\mathrm{a}_{1} \log \mathrm{GDP}+\mathrm{a}_{2} \log \mathrm{REV}_{-1}+\mathrm{e} \\
& \log \mathrm{EXP}=\mathrm{b}_{0}+\mathrm{b}_{1} \log \mathrm{GDP}+\mathrm{b}_{2} \log \mathrm{EXP}_{-1}+\mathrm{e}
\end{aligned}
$$

Government revenues and expenditures are considered very important indicators. Their elasticities reveal the behavior of 
government fiscal policies and the consistency between government domestic revenues and expenditures. Through equations 1 and 2, we can determine the degree to which the government's fiscal policies are able to adapt to the economic situation in the short term. In addition, these equations make it possible to estimate the elasticities of domestic revenues and government expenditures in the long run. The long-term elasticity of domestic revenues equals $a_{1} /\left(1-a_{2}\right)$. The long-term elasticity of government expenditures equals $b_{1} /\left(1-b_{2}\right)$.

Using this method, if the elasticity of expenditure is greater than the elasticity of revenue, then the growth rate of government expenditure exceeds the growth rate of revenue. In other words, government spending is higher than its long-term income, and thus, can disrupt the public finances of the government.

This paper will use the method of Fully Modified Least Squares (FMOLS). It is characterized as a method of cointegration to estimate long-term relationships. This methodology solves the problem of autocorrelation and endogeneity between most time series and the nonstationarity of time series. However, the first step is to test for stationarity. Table 1 shows the results of the stationarity test for the variables.

Table 1: Unit Root Test Results for REV, EXP, and GDP

\begin{tabular}{|c|c|c|c|c|}
\hline $\begin{array}{c}\text { The } \\
\text { variable }\end{array}$ & $\begin{array}{c}\text { Calculated } \\
\text { value }\end{array}$ & $\begin{array}{c}\text { Critical } \\
\text { value }\end{array}$ & decision & notes \\
\hline REV & 3.25 & 3.22 & $\begin{array}{c}\text { y } \\
\text { ftationar }\end{array}$ & first difference \\
\hline
\end{tabular}




\begin{tabular}{|c|c|c|c|c|} 
EXP & 3.34 & 3.22 & $\mathrm{y}$ & first difference \\
\hline GDP & 11.27 & 2.64 & $\mathrm{y}$ & difference \\
\hline
\end{tabular}

To apply the FMOLS, the residuals of the equations must be stationary at the level, so that the coefficients of the equations can be cointegrated.

The estimation of equations 1 and 2 gave the following results. $\log \mathrm{REV}=-0.05+0.23 \log \mathrm{GDP}+0.0 .75 \log \mathrm{REV}_{-1}$

$$
\text { p-value (0.0005) (0.000) }
$$

$\log \mathrm{EXP}=-0.08+0.58 \log \mathrm{GDP}+0.36 \log \mathrm{EXP}_{-1}$

$$
\text { p-value (0.0011) (0.051) }
$$

After calculating the long-term elasticities of both government expenditure and domestic revenues in Jordan, the elasticity of local revenue was found to be 0.92 , and the elasticity of public expenditure was 0.91 . The result of almost equal elasticities of both expenditures and revenues supports only the weak sustainability of public debt.

This measure is based on the existence of cointegration between domestic revenues (REV) and government expenditures (EXP). This relationship takes the following form:

$$
\mathrm{REV}_{\mathrm{t}}=\rho_{1}+\rho_{2} \mathrm{EXP}_{\mathrm{t}}+\varepsilon_{\mathrm{t}}
$$

If there is cointegration between local revenues and government expenditures and the value of $\rho_{2}=1$, this means the public debt is sustainable. On the other hand, sustainability does not exist if cointegration is not achieved or the value of $\rho_{2}<1$. 
The results of the Johannsen cointegration test between revenues and expenditures in Jordan for the period from 1982 to 2015 are shown in Table 2. The test results indicate a single vector for cointegration at a $5 \%$ level as the calculated $(\mathrm{t})$ value is greater than the tabulated one.

Table 2: Cointegration Test Results

\begin{tabular}{|c|c|c|c|c|}
\hline $\begin{array}{c}\text { Hypothesized: No. of } \\
\text { CE(s) }\end{array}$ & $\begin{array}{c}\text { Eigenva } \\
\text { lue }\end{array}$ & $\begin{array}{c}\text { Trace } \\
\text { statistic }\end{array}$ & $\begin{array}{c}\text { Critical Value } \\
5 \%\end{array}$ & Prob. \\
\hline None $*$ & 0.411 & 18.553 & 15.494 & 0.01 \\
\hline At most 1 & 0.067 & 2.155 & 3.481 & 2 \\
\hline
\end{tabular}

The estimated equation is as follows:

$$
\mathrm{REV}_{\mathrm{t}}=84.3+0.683 \mathrm{EXP}_{\mathrm{t}}
$$

The results show that both domestic revenue and public expenditures are cointegrated. However, the expenditure factor $(\rho)$ was less than one. In addition, the results show a large gap between revenues and expenditures. When expenditure increases by 1 million, revenue increased by only 0.683 million. These results give no indication of sustainability of the fiscal policies, and therefore, no sustainability in the public government debt in Jordan.

OMAR (2003) presented a method for measuring the sustainability of public debt. This method is based on the idea of testing the cointegration between public debt and both the balance of trade, TB, and GDP. The model is written as: 


$$
\mathrm{DET}=\mathrm{a}+\mathrm{b} \mathrm{TB}+\mathrm{c} \text { GDP }+\mathrm{u}_{\mathrm{t}}
$$

To achieve sustainability, we should have cointegration among the variables, and the coefficient (b) should equal to 1. Using the twostage Angle-Granger method, the first stage tests for the long-run equilibrium among the variables or cointegration. Before that can be tested, it is necessary to check for the stationarity of the variables. Table 3 shows the results of stationarity using the Augmented Dickey Fuller (ADF) test.

Table 3: Unit Root Test Results for Fourth Model Variables

\begin{tabular}{|c|c|c|c|c|}
\hline $\begin{array}{c}\text { The } \\
\text { variable }\end{array}$ & $\begin{array}{c}\text { Calculated } \\
\text { value }\end{array}$ & $\begin{array}{c}\text { Critical } \\
\text { value }\end{array}$ & decision & Notes \\
\hline BD & 6.29 & 2.64 & $\begin{array}{c}\text { stationar } \\
\text { y }\end{array}$ & $\begin{array}{c}\text { second } \\
\text { difference }\end{array}$ \\
\hline TB & 4.3 & 2.65 & $\begin{array}{c}\text { stationar } \\
\text { y }\end{array}$ & $\begin{array}{c}\text { second } \\
\text { difference }\end{array}$ \\
\hline GDP & 11.27 & 2.64 & $\begin{array}{c}\text { stationar } \\
\text { second } \\
\text { difference }\end{array}$ \\
\hline
\end{tabular}

The results of the stationarity test show that public debt and real GDP are stationary at their second difference. However, the trade balance is stationary at the first difference. Therefore, we proceed to check for cointegration among the variables. The results appear in Equation 8.

$$
\mathrm{DET}=2194.43-2.99 \mathrm{~TB}+0.49 \mathrm{GDP}+\mathrm{u}_{\mathrm{t}}
$$

t-stat. (2.8) 


$$
\mathrm{R}^{2}=0.15 \quad \mathrm{DW}=1.4
$$

Given the modest value of $\mathrm{R}^{2}$, some may not place much trust in interpretations based on this equation. However, the results allow one to move to the second stage of testing whether the residual series resulting from equation 8 is stationary or not. If the residuals are found to be stationary, then this is evidence of cointegration. In other words, there is a long-term cointegrated equilibrium relationship between the variables. The results for the ADF test show that the calculated value is greater than the critical value at $10 \%$ level. Thus, we can conclude that the residuals of the equation are stationary. This means a stable longterm relationship exists among public debt, GDP, and trade balance. Accordingly, sustainability is achieved.

\section{CONCLUSION}

The main objective of this study was to examine the sustainability of public debt in Jordan. Internal and external public debt has shown steady increases. During some years, debt reached critical levels and exceeded the percentages set by the public debt law in other years. Therefore, the structure of the public debt poses a risk to the public finance policies, since the burden of this debt continues to be the most important source of pressure on the government budget. A number of methods were used to determine the sustainability of public debt. We compared real interest rates and real economic growth rates. We tested for cointegration between revenues and expenditures. We 
compared the elasticities of revenues and expenditures, and we tested them for cointegration among public debt, trade balance, and GDP. The results of all of these indicators could be summarized as describing the sustainability of public debt in Jordan as weak.

Accordingly, this study recommends finding public debt management that seeks lower-cost sources of finance to strengthen the sustainability position. In addition, it is necessary to comprehensively review all items of the public expenditure, prevent unnecessary spending, and direct spending towards productive projects.

\section{REFERENCES}

ABDUL-RAHIM, M., SHIBANI, A., SHAKORY, S. (2013). "Sustaining of the Budget Deficit in Algeria: Empirical and NonLinear Facts Using the STAR Model". Setif University. Algeria.

AKHTAR, S., ARSHAD, M. A., MAHMOOD, A., \& AHMED, A. (2018). "Gaining recognition of Islamic spiritual intelligence for organisational sustainability". International Journal of Ethics and Systems. Vol. 34, No 1: 70-77. USA.

BAGHDADI, M. (2011). "Indicators of Financial Sustainability and Threats in Egypt". Unpublished Ph.D. thesis, Mansoura University, Mansoura. Egypt.

BELHOCINE, N., \& DELEBRA, S. (2013). "The Impact of Debt Sustainability and the Level of Debt on Emerging Markets Spreads". IMF Working Paper. Egypt. 
BLANCHARD, J. (1990). "Suggestions for a New Set of Fiscal Indicators". OECD Working Paper. No 79, pp. 48-73. Egypt.

CONSIDINE, J., \& GALLAGHER, L. (2008). "UK Debt Sustainability: Some Nonlinear Evidence and Theoretical Implications". The Manchester School. Vol. 76, № 3: 320-335. USA.

EDWARD, S. (2002). "Debt Relief and Fiscal Sustainability". NBER Working Paper. No 8939 . USA.

FEREDE, E. (2005). "External Public Debt, Economic Growth and Welfare Gains from Debt Relief for HIPCs". Unpublished Ph.D. dissertation, Edmonton Alberta. Canada.

HERNDON, T., ASH, M., \& POLLIN, R. (2013). "Does High Public Debt Consistently Stifle Economic Growth? A Critique of Reinhart and Rogoff'. Political Economy Research Institute, University of Massachusetts Amherst, Working Paper series. № 322. USA.

JUNOHAT, V. (2006). "The Problem of External Debt and Its Effects on Economic Development in the Arab Countries: The Case of Some Indebted Countries". Unpublished Doctoral Thesis. Algeria.

MENDOZA, E., \& OVIEDO, P. (2009). "Public Debt, Fiscal Solvency and Macroeconomic Uncertainty in Latin America the Cases of Brazil, Colombia, Costa Rica and Mexico". Economía Mexicana Nueva Época. Vol. 28, № 2: 133-173. UK.

NIKKU, B. R., \& RAFIQUE, Z. (2019). Empowering people: Role for political social work in South Asia. International Social Work, Vol. 62, No 2: 877-891. UK.

OMAR, M. (2003). "Public Debt: Concepts, Indicators, and Effects: The Case of Egypt”. Al-Azhar University. Cairo, Egypt. 
SHABBIR, M. S., ABBAS, M., AMAN, Q., \& ALI, R. (2019). "Estrategias de reducción de la pobreza. Explorando el vínculo entre pobreza y corrupción de países menos desarrollados". Dilemas Contemporáneos: Educación, Política y Valores, Vol. 86, № 2. Mexico. 



\section{DEL ZULIA}

opción

Revista de Ciencias Humanas y Sociales

Año 35, N²4, (2019)

Esta revista fue editada en formato digital por el personal de la Oficina de Publicaciones Científicas de la Facultad Experimental de Ciencias, Universidad del Zulia.

Maracaibo - Venezuela

www.luz.edu.ve

www.serbi.luz.edu.ve

produccioncientifica.luz.edu.ve 